introduction to this second edition, Dr. Earland sets out the plan of his revision. The list of contents follows closely the original scheme; certain chapters have received particular attention and include much new material, while the others (that is, Chapters 2-7) "have been scrutinized for errors and brought up to date".

Implementation of this plan is unfortunately only partially effective, as an examination of the references cited shows. Those chapters which incorporate new material now contain, on average, about 25 per cent of more recent references. Of these, only about one in five is taken from conference proceedings, despite the fact the, many of the advances in understanding arose from the three major conferences held since the first edition. In Chapters 2-7, there are only five new roferences in a total of nearly five hundred and there is very little alteration to the text; even the duplication of part of a paragraph on felting action on $p p .41$ and 43 , which was an irritating feature of the first edition, still stands. In Chapter 6 , work by Larose $(1955,1960)$ on the sorption of acids by wool receives no mention; while a contribution to the otherwise scanty literature on the uptake of nonionic dyes by wool by Bird and Firth (1960) is ignored in Chapter 7 .

Similar examples can be quoted in those chapters which have been extensively amended. In Chapter 8 it is stated that iodine does not oxidize the disulphide bond, although Crewther (1960) has produced ovidence to the contrary. An astonishing omission from Chapter 9 is that of the urea-bisulphite solubility test, introduced by Lees and Elsworth in 1954 and the subject of numerous papers since. The test is of value in assessing alkali damage, for which purpese the alkali-solubility test, which recoives a full discussion, is recognized to be unsuitable.

These shorteomings of the revision indicate the dilemma facing Dr. Earland. The original authors stated in their preface "that no attempt has been made . . . to provide a complete bibliography". The problem of the selection of material becomos much moro serious in bringing the monograph up to date; yet without reasonably comprehensive coverage the value of the book is diminished. One possible solution would have been to provide a general bibliography, including the important socondary sources $\rightarrow$ such as the Review of Textile Progress, and Advances in Protein Chemistry, to give but two examples-from which the reader could compile his own comprehensive set of references.

This second edition, then, is somewhat disappointing in that the opportunity to set out a full account of the present state of the knowledge of this subject was not taken. However, the book still holds an important position in this field, since it does provide in one volume much of the varied and widely scattered information of which any student or research worker must be aware.

J. M. Woophouse

\section{OUT IN THE MIDDAY SUN}

\section{Journey to the Jade Sea}

By John Hillaby. Pp. vii $+234+20$ photographs. (London: Constable and Co., Ltd., 1964.) 30s. net.

$\mathrm{B}$ OOKS by writers who go to Africa in search of their souls aro always interesting to us who went there in search of wages; this book is fascinating. "Essentially, I walked into the N.F.D. for the hell of it" (p. 2); Mr. Hillaby took his own hell by using a small string of unhealthy camels for transport instead of a lorry or Land-Rover, as do other people in that part of Kenya. "Porhaps all safaris start this way. Somewhat despondently ..." (p. 7); they do not, but I should have been despondent if $I$ had started with that collection of provisions (much rice for desert travel) in old cardboard boxes to be carried on a poor lot of camels at a season when rains wore threatening.

Mr. Hillaby wanted to travel in a desert, and he took the advice of $\mathrm{Mr}$. Thesiger on desert travel. But the country he traversed does not accord with the definition of a desert-a waterless and treeless region-for his tale makes many references to rain and mud, and the photographs show many trees. Nor is the Serengeti a desert, as stated on the cover of the book; the first time I went there, my car stuck in the mud; and I could not go in 1963 because the airstrip was under water. Hillaby must be tough to have walked to Lake Rudolph after training in walking on the South Downs and in London, with canvas shoes and no socks, no shirt, a few words of Swahili, two guns and no experience of shooting. We are not told if his back peeled, if his feet got blisters or if his scratches went septic; he got there.

Then Hillaby had the wonderful good fortune to go through the game reserve on the east of the lake, to which I have looked. longingly from the mountains on the west, and he went with the Warden who knew the country, who ran the safari and provided guards against Marille raider's. Yet he continuod to think that he was in a dosert, while the Warden wore brown boots, puttees and hoavy khaki drill (and, presumably, a shirt) under the impression that he had work to do in a rocky region abounding in thorns and snakes: "I also had the feeling that he oxpected me to make a meticulous count of what were mostly indistinguishable antelope in a blur of dust" (p. 141); that is what good game wardens do.

This might have been the most interesting part of the book. "Wo covered the seventy-five miles between Allia Bay and North Horr in four stages; there is not much I care to say about any of them" (p. 142). "After a few days of gadding about in a Land-Rover with the Warden on a ration-buying oxpedition, we said goodbye and went about our own affairs" (p. 144). Then we revert to a saga of unloading camels, missed shots, unappetizing meals and conversations in about twenty words of Swahili.

"As a writer and naturalist I had travelled widely without seeing very much at close quarters" (p. 2). Mr. Hillaby was bored in his travels "and tried to think of something to think about" (p. 152); "to relieve boredom" (p. 181); "I used to imagine that I could always fird something of biological interest in a new place before $I$ ventured into the Northern Frontier District" (p. 182). The photographs are mostly of Africans, camels and Mr. Hillaby, but one shows Encephalartos tegulaneus on Mt. Lolokwi, the only place where it had been recorded in Kenya; but that is not montioned in tho text. There is reference to hut circles on p. 92, but no photograph of thom; did they, like those in the west, have grindstones nearby to show that they were built by former cultivator: and not by recent pastoralists?

Wo are told that Mr. Hillaby is "an ardent conservationist". What does he want to conserve, a desert with camels, or a large mountainous district with a variety of climates, a population of warring tribes, who own large numbers of domostic stock, including a fow camels, and a wonderful assortment of wild plants and animals? That is what the Warden and his colleagues are trying to safeguard. "South Horr has been ravaged by raiding tribes (including tho British) for a very long time" (p. 74); that is an unjust jibe at an administration whose members gave so much help and hospitality to $\mathrm{Mr}$. Hillaby.

All's well that ends well. Mr. Hillaby learnt of the skill and resourcefulness of Africans (p. 2) and of the hard work of white hunters (p. 221). "Boredom certainly had a lot to do with it and that boredom had been wholly roplaced with a reservoir of self-confidence" (p. 234).

Messrs. Constable havo published a most interesting book. They might also publish an interesting one by the Warden, for he no doubt would tell us more about the animals and plants.
A. S. Thomas 